\title{
A Team-Teaching Model in an Informal Cooperative Learning Classroom
}

\author{
https://doi.org/10.3991/ijet.v14i20.11458
}

\author{
Kamilah Radin Salim ${ }^{(凶)}$, Morina Abdullah, Habibah Norehan Haron, \\ Noor Hamizah Hussain, Ruzana Ishak \\ Universiti Teknologi Malaysia, Skudai, Malaysia \\ kamilah.kl@utm.my
}

\begin{abstract}
Research has indicated that informal cooperative learning (ICL) can make the environment in a classroom more conducive for teaching and learning. Through ICL, students could focus their attention on the material taught in class and help each other in the learning process. However, implementing ICL may require more time and effort from the lecturers because they need to prepare teaching materials and different tasks for class activities. Sometimes it may be difficult for the lecturer to monitor all students in the groups when implementing ICL. Thus, this study aimed to explore the implementation of team-teaching in ICL classroom. The action research method was used in this study where the researchers themselves involve in implementing ICL through team-teaching, evaluate the process, do reflection and change the practice based on the evidence gathered. The participants were 32 first-year-students who were mainly exposed to the traditional method of lecture. Students' and lecturers' activities, behaviors, interactions, and reflections were recorded in a research journal and later analyzed to determine the students' and lecturers' experience in ICL classroom conducted through team-teaching. The findings showed that it was easier to monitor and facilitate the students as well as to manage the class by implementing ICL through team-teaching. In addition, the workload of the lecturers has reduced which in turn gave them more time to plan, prepare and organize teaching materials.
\end{abstract}

Keywords - Cooperative Learning, Informal Cooperative Learning, TeamTeaching, Teaching and Learning, Teamwork

\section{$1 \quad$ Introduction}

Contemporary teaching methods focus on active learning approaches such as cooperative learning, problem-based learning, peer instruction, and scenario-based learning. The term cooperative learning refers to students working in a group or team in doing assignments or project under certain conditions. Cooperative learning is a learner-centered approach that consists of small groups or teams of students, who work together to maximize their own and each other's learning [1]. In cooperative learning, students learn by participating in the class activities rather than sitting passively, watching and listening to the lecturers. 
Studies have indicated that cooperative learning could develop students' problemsolving skills and ensure students' active cognitive processing during lectures [1], generate positive attitudes towards the subject studied and the improve overall learning experience [1][2]. In addition, students could also develop their interpersonal relationships and, hence avoid the sense of isolation [1][2]. Furthermore, if the students remained in a particular group for the whole semester or throughout the same course, the group members could provide continuing support and assistance for each other's academic advancement [3]. Thus, by involving in cooperative learning, students' motivation to learn, productivity and achievement as well as social skills could be enhanced.

However, not all students and lecturers are familiar with the cooperative learning method. Students may not fully cooperate in the group work. A study by [4], found that students tended to socialize instead of working together to solve the given problems. Lecturers, on the other hand, may encounter challenges and difficulties in implementing cooperative learning in their classroom. Among the challenges and difficulties reported were preparing teaching materials and suitable tasks for students' activities [4][5][6], assessing students' performance [4][5] and managing noisy and chaotic classroom [5]. The experience of one of the authors [7] who implemented informal cooperative learning in her class indicated that it was challenging to control, monitor and assist all students in the class especially when it involved a large number of students (i.e. more than 30 students). It was also tiring to handle the class alone because she has to walk around most of the time during the class period to ensure that all students were attended to.

Considering the aforementioned teaching and learning challenges of cooperative learning, two of the authors implemented team-teaching in an informal cooperative learning classroom. Therefore, this paper discusses (i) lecturers' experience in implementing informal cooperative learning through team-teaching, (ii) students' experience in participating in an informal cooperative learning classroom.

The following definition for informal cooperative learning and team-teaching are used in this paper. Informal cooperative learning is a temporary ad-hoc group or team that can last from a few minutes to one class period [1][3]. Team-teaching refers to a situation in which two or more lecturers teach the same group of students at the same time [8].

\section{$2 \quad$ Literature Review}

\subsection{Cooperative learning}

Cooperative learning is characterized by positive interdependence, where students perceived that the better performance of individuals produces a better performance of the entire group [9]. It can be formal or informal, but often involves specific instructor's intervention to maximize student's interaction and learning. It is infinitely adaptable, whether in small and large classes and across disciplines and can be one of the most effective teaching approaches at college or university levels. 
Previous studies have indicated that the application of cooperative learning in teaching and learning could improve students' learning and understanding. Cooperative learning delegates authority to students to direct their own learning within the context of the task given. It could enhance students' learning in several ways. For example, weak students who work on their own are likely to give up when they get stuck. However, by working cooperatively, they keep on going because they have the responsibility to ensure the success of their group [10]. Furthermore, in cooperative learning, good students can improve their understanding and communication skills by explaining and clarifying the subject matter to weaker students within their group [10]. Students may also have different opinions on certain issues. Thus, discussion with the group members will help the students to develop reasoning skills and higher quality of understanding on the subject matter [11]. As a result, students' will improve their social skills and the way they argue and interact with others.

A study by reference [12] in science-technology laboratory application indicated that students who participated in cooperative learning laboratory-developed their skills in identifying laboratory equipment better than the students in the group in which traditional learning method was used. Reference [11] implemented cooperative teaching and learning activities in a science subject to 11-year-old school students. The author reported that the students' participation in cooperative learning activities had trained them to be better learners. Through cooperative learning, they learned to interact with each other, generated alternative ideas and made inferences through discussion [11]. Thus, by properly implementing cooperative learning, it is expected that the students will have better achievement in the cognitive, psychomotor and affective skills compared to students who learn in a traditional way.

Cooperative learning is a situation in which students work together to achieve shared goals and positive outcomes [2]. Therefore, they need to discuss the course materials, help one another to understand the subject matter and to encourage their group members to work hard for the success of their group [2]. Thus, one of the important requirements for cooperative learning is that every group member is individually accountable for the complete content of the assignment or project [7]. There are five important components for a small group learning to be truly cooperative. These are:

- The group must have clear positive interdependence

- Members in the group must promote each other's learning

- Each student in the group is individually accountable to do his/her fair share of the work

- Members in the group should use interpersonal and small-group skills appropriately

- Group members should have the opportunity to discuss their group progress and maintain their working relationships [1][13].

There are three types of cooperative learning [1][3][13]. These are:

- Formal cooperative learning

- Informal cooperative learning 
- Cooperative based groups. When implementing cooperative learning, the lecturer could divide the students into any types of groups, depending on the objectives of forming the group and the duration group members stay in that particular group. Formal cooperative learning group is formed to complete a specific assignment or task for the duration of one class period to several weeks, depending on the complexity of the assignment [1]. On the other hand, informal cooperative learning group is a temporary, less formal and may last for a topic of discussion or one class period [1][13]. A group that is formed and maintained for the entire course, i.e. for a semester-long is known as cooperative base groups [1][13]. Since this study focuses on informal cooperative learning (ICL) classroom, the authors will further discuss on ICL only.

\subsection{Informal cooperative learning}

Informal cooperative learning is a temporary ad-hoc group or team that can last from a few minutes to one class period where groups of two to four students work together to answer questions asked by the lecturer [1][3]. According to [1][3][13], the purposes of ICL are to focus students' attention on the material to be learned, to set students' mood and motivation to learn and to ensure students cognitively process the material taught. In ICL, students engaged in short activities as respond to questions post by the lecturer about what is being learned [14]. Thus, students' misconceptions, incorrect understandings, and gaps in understanding could be identified and corrected immediately [1]. As a result, students' learning experiences would be enriched. ICL could be used during normal lecture or demonstration [1]. When implementing ICL, the lecturer should provide a conclusion to the lecture material at the end of the class session [14]. Examples of ICL that could be implemented in a classroom are Thinkpair-share, Peer instruction and Jigsaw [9].

In a Think-pair-share ICL, first, the lecturer asks a question and students are instructed to think or write about the answer to the question. Then, he/she turns to a peer next to him/her to discuss their answer. Lastly, each group shares their answer with the class. Peer instruction method is a modification of the Think-pair-share method which involves a personal response device (i.e. a clicker) [9]. The question posed by the lecturer is typically a multiple-choice conceptual question. Students think about their answer and vote on a response before turning to a peer next to him/her to discuss. Students can change their answers after discussion, and "sharing" is accomplished when the lecturer revealed the graph of student's response and used this as a motivation for class discussion. This approach is particularly suitable for large classes.

Jigsaw ICL approach consists of two rounds. Round 1 is known as a focus group where students work in a group/team (i.e. four students per group). Each group is given a different material to read and discuss such that every member in the group become experts on that new material. In round 2, a new group forms which are known as task groups. The members of task groups consist of one member from each expert group. They take a turn teaching each other about the material he/she is an expert on [9]. 


\subsection{Challenges and difficulties in implementing cooperative learning}

Despite the benefits of cooperative learning to students' learning and achievement, previous studies also found that the implementation of cooperative learning requires a lot of effort and work from the lecturer. These challenges and difficulties can be group into a few themes as follows:

- To group the students (i.e. group size, group member) [4][5][6]

- To control socializing among the group members [4][6]

- To guide students to cooperate in the group [4][5][6]

- To prepare teaching materials and tasks for students' activities [4][5][6]

- To train the students to report group work [6]

- To assess students' achievements [4][5][6]

Thus, this paper will discuss one of the methods that could probably overcome the challenges and difficulties in implementing cooperative learning.

\section{$2.4 \quad$ Team-Teaching}

In general, the term team-teaching is used when more than one lecturer teaches a course. Reference [15] and [16] stated that team-teaching involves "two or more faculty at some level of collaboration in the planning and delivery of a course". Teamteaching is a situation where a group of two or more lecturers works together to conduct teaching and learning activities [8]. In general, team-teaching requires the cooperation of two or more lecturers in preparing the teaching and learning materials and activities and managing the class.

According to reference [17], working as a team requires the team members to respect differences, interdependence, and conflict-resolution skills. Team members should sit together to set the course objectives and content, select common course materials and develop tests and final examinations for all students. They set the same sequence of topics and supplemental materials. They also give their own interpretations of the materials and use their own teaching styles. The greater the agreement on common objectives and interests, the more likely that teaching will be synchronized.

Reference [8] divided team-teaching into two categories. The first category is where two or more lecturers teach the same group of students at the same time in the same classroom. The second category also requires the involvement of more than one lecturer, however, they do not teach the same group of students. In this case, known as parallel team-teaching, the lecturers divide the students into two groups and each lecturer teaches the same teaching materials to his/her group [18].

Reference [19] divided team-teaching into three types; interactive teaching model, rotational model, and dispersed team model. In the interactive teaching model, a few lecturers teach one course and all members of the teaching team are present during every lecture of the course. A rotational model consists of a few lecturers teaching one course, but only one lecturer teaches during each class session. Each lecturer teaches the topics that fall within his/her expertise. In a dispersed team model, the class meets two or three times a week throughout the course. Once a week, all of the teaching 
team will be in the class session whereas, during other times, only one lecturer will be teaching the course. Reference [16] divided the team-teaching model into five categories which range from the low level of collaboration to a high level of collaboration among the team member.

The main purpose of team-teaching is to enable students to achieve a higher level of integration and synthesis in studying new topics [19]. In addition, team-teaching allows a more flexible and creative learning environment which could enrich students' professional development and educational experience at the university [20]. Other educational advantages of team-teaching include increasing students' level of understanding and retention as well as enabling students to obtain higher achievement [8].

Team-teaching also possesses many pedagogical and intellectual advantages such as to create a dynamic and interactive learning environment and intellectual partnership among lecturers [19]. Through team-teaching, the different skill sets, background, and knowledge of each lecturer could be shared among the lecturers [15]. The lecturers could also discuss issues relating to students, such as students' behavior and motivation, as well as matters pertaining to teaching policies [8]. In short, teamteaching could benefit both students and lecturers. The lecturers could work together professionally to ensure the success of their students. By learning in an interactive environment and observing lecturers managing the class through team-teaching would help to develop positive values among the students. However, the students could also be confused when they were taught by more than one teacher in the classroom. This disadvantage of team-teaching is reported by [16].

For a team-teaching to be successful, the responsibilities of each lecturer in the team should be clearly stated and they should communicate with each other regularly [8]. In addition, the team members should be well-matched and committed to ensuring smooth implementation of team-teaching [8]. In other words, the team-teaching should be planned properly by the team members to ensure its accomplishment.

Anderson and Landy who employed team-teaching at Stanford University proposed several guidelines in implementing team-teaching [19]. These include:

- Team members should plan their class and course together

- Team members should refer to each other during class

- Team members should attend all class sessions

If only one lecturer is responsible for presenting the topic during the class session, the other lecturer should assist in helping the students to better understand the material presented.

Table 1 presents the summary of definitions and models of team-teaching discussed above.

Table 1. Definition and Models of Team-Teaching

\begin{tabular}{|l|c|l|}
\hline Researcher & Model & \multicolumn{1}{c|}{ Definition / method } \\
\hline Reference [8] & A & $\begin{array}{l}\text { Two or more lecturers teach the same group of students at the same in the same } \\
\text { classroom. }\end{array}$ \\
\hline Reference [8] & B & Two or more lecturers, teach the same material to a different group of students. \\
\hline Reference [18] & Parallel & Students are divided into two groups and each lecturer teaches the same teach- \\
\hline
\end{tabular}




\begin{tabular}{|c|c|l|}
\hline & $\begin{array}{c}\text { team- } \\
\text { teaching }\end{array}$ & ing materials to his/her group. \\
\hline Reference [19] & $\begin{array}{c}\text { Interactive } \\
\text { Teaching } \\
\text { Model }\end{array}$ & $\begin{array}{l}\text { A few lecturers teach one course and all members of the teaching team are } \\
\text { present during every lecture of the course. }\end{array}$ \\
\hline Reference [19] & $\begin{array}{c}\text { Rotational } \\
\text { Model }\end{array}$ & $\begin{array}{l}\text { A few lecturers teaching one course, but only one lecturer teaches during each } \\
\text { class session. Each lecturer teaches the topics that fall within his/her expertise. }\end{array}$ \\
\hline Reference [19] & $\begin{array}{c}\text { Dispersed } \\
\text { Team } \\
\text { Model }\end{array}$ & $\begin{array}{l}\text { The class meets two or three times a week throughout the course. Once a week, } \\
\text { all of the teaching team will be in the class whereas, during other times, only } \\
\text { one lecturer will teach the course. }\end{array}$ \\
\hline
\end{tabular}

From Table 1, it can be concluded that the interactive teaching model proposed by [19] is similar to Model A proposed by [8]. This is the model employed by two of the authors of this study in implementing team-teaching in an ICL classroom which will be discussed in the following section.

\section{$3 \quad$ Methodology}

The focus of the study is to discuss the authors' experiences and reflections in implementing team-teaching in informal cooperative learning (ICL) classroom as well as to explore the students' experiences in the ICL classroom.

\subsection{Research method}

This study adopted an action research strategy whereby the researchers themselves involve in implementing ICL through team-teaching, evaluate the process, do reflection and change the practice based on the evidence gathered [21]. By engaging in action research, the authors believed they could improve the teaching and learning activities in the class as well as the way they manage and practice the team-teaching. In addition, they could also gather valid and reliable data for the research. Action research is employed by the practitioners as a way to improve their practice and increase their knowledge and understanding about the real situations they are involved in [22]. Furthermore, action research is always relevant to the researchers because the focus of the research is determined by them and the findings of the research are also useful to them [23].

\subsection{Participants}

The first group of participants in this study was 1st year students of a Diploma in Electrical Engineering program, a three-year program at one of the higher learning institutions in Malaysia. The study was conducted when the students were in their $2^{\text {nd }}$ semester. There were 32 students in the class. The second group of participants was $2^{\text {nd }}$ year undergraduate students who were in their $3^{\text {rd }}$ semester. There were 25 students in the class.

The course involved was Basic Electronics, which was a three-hour lecture and a one-hour tutorial course. The class sessions were held twice weekly where each class 
lasted for one hour and forty minutes. It was a common practice to treat the tutorial session as a class session in this program. It should be noted that only two of the authors implemented ICL through team-teaching in this study. Both of them were lecturers who have been teaching Basic Electronics course in previous years.

\subsection{Implementation}

Referring to Table I, this study employed an interactive teaching model in implementing team-teaching in ICL classroom. Two weeks before the class started, the two lecturers discussed the implementation of ICL through team-teaching. Following was the strategy used by them:

- Pre-assigned the group members (three to four students in a group). However, with some justifications, students were allowed to change their group members

- Divided the lectures into a few slots depending on the subtopic of the course content

- Gave exercises and quizzes for students to discuss and solve within their ICL group during class

- Gave assignments like homework and asked students to discuss and solve the assignments within their ICL group

- Walked around the class while the students discussed the solution to the exercises and quizzes. Ensure all students in ICL groups participate in the discussion

- Monitored every group and assisted groups/students who need guidance

- Sometimes ask students to solve and explain their solution in front of the class. Commented on the answers/solutions provided by the students

- Conclude the materials taught at the end of every class

- Gave points (a sticker) to every group during the class activity

- Gave rewards to the top three groups at the end of the semester

The ICL engaged by the lecturers were similar to Think-pair-share method, but the groups consisted of three to four students and they remained in the same group throughout the course. The lecturers also requested every group of students to prepare one notebook. The procedures and solutions for the exercises given during class session were written in this notebook. The awarded stickers were also affixed inside the notebook. The lecturers collected the notebook once a week. Example of the notebook is provided in Appendix 1.

\subsection{Data collection and data analysis}

One of the important steps in applying action research is to keep a research journal which comprises all research activities such as conversations, observations notes, description of conditions of an interview, comments, ideas and memos about research issues, photographs, and reflections of the researchers [21]. Following this procedure, both lecturers noted students' behaviors and interactions during class as well as their own activities and reflections in a research journal. 
Student feedbacks were collected at the end of the semester. Every student was asked to write his/her learning experiences in ICL classroom. The lecturers' observation notes, and reflection notes and students' feedbacks were sorted by content analysis. The coding and recoding took place where the authors reviewed and revised the data to ensure that the categories identified were representative of all the data collected.

\section{$4 \quad$ Results and Findings}

As mentioned earlier, the objectives of this study were to: (i) explore lecturers' experience in implementing team-teaching in ICL classroom; (ii) explore students' experience in participating in the ICL classroom. Therefore, the results and discussion are presented according to the stated objectives.

\subsection{Lecturers' Experience}

The result of this study showed that implementing team-teaching in ICL classroom (or any classroom) could reduce the workload of the lecturers, hence, gave them more time to organize the teaching material in advance. Through team-teaching, the workload such as preparing teaching materials and tasks for students' activities were shared by both lecturers. Each lecturer was given the assignments, exercises, quizzes, and tests to prepare and grade. Thus, students' assignments, exercises, quizzes, and tests were promptly returned to the students compared to when the class was handled by only one lecturer.

The authors found that implementing team-teaching did not require any extra time compared to when teaching the course alone. This finding contradicts the findings reported by [8][15] who stated that a lot of time was needed in implementing teamteaching which included planning the course design, meeting and discussing during the running of the course. The main reason for the difference in the findings in this study and earlier studies could be because both lecturers in this study used to discuss and share their teaching materials when they taught the course alone in previous semesters. Moreover, it is a common practice in this program for students who register for a particular course to sit for the same tests and final examination and at the same time. Thus, implementing team-teaching did not require any extra effort from the lecturers.

Other advantages of team-teaching are the class was never canceled or postponed. If one of the lecturers could not attend the lecture, the class could still proceed as the other lecturer was still available. In addition, it was easier to attend to students when there were two lecturers in the same classroom, thus ensuring full participation and facilitation of the students, Furthermore, team-teaching improved the authors teaching and the way we team-worked and communicated with colleagues.

From the authors' experience, two main reasons for noisy and chaotic classroom environment during ICL were due to students calling the lecturers asking for assistance and when they were asked to share their answers verbally with the whole class 
or to write and explain their solutions in front of the class. Knowing that they would receive the sticker if they volunteered, the students loudly said "our group" or "we want to try" besides raising their hands. Therefore, it was easier to identify which group volunteered first and thus avoid the sense of favoritism when there were two lecturers in the class.

From this study, the authors also discovered that students who were grouped with the same gender interacted more actively compared to those who were in mixedgender groups. This may be due to their cultural and educational background. Not much resistance was put up by the students to the group membership proposed by the lecturers. This could be due to the fact that first-year students do not normally have any preference in choosing their group members.

Rewarding the groups during every class also encouraged the students to put more effort and helped each other in solving the exercises or quizzes. By working in groups, it was observed that students' use of hand phone during class was less because they had to contribute to the discussion. If any of the group members kept on using the hand phone for a personal matter, the other group members would remind him/her. The lecturers also reminded them about the use of hand phone during the class session.

On the last day of class, when the authors gave rewards (hamper with biscuits, sweets, and chocolates) to the top three groups, they shared the rewards with the whole class. The students' satisfaction and enjoyment were evident.

\subsection{Students' learning experience}

Depending on their educational background and previous schools, students may or may not have prior experience of cooperative learning method in the classroom. By participating in ICL, students could experience working together in a group and learn to value each other's contributions to the success of their group. Students commented that the ICL method was fun and they enjoyed the comfortable, calm, open, cheerful and interesting learning environment. Another remark by students was that the teaching and learning method was effective and should be continued as it allowed students to become closer to their classmates and lecturers.

According to the students, the group learning style should be maintained because team-working made it easy for them to solve the exercises, quizzes, and assignments given to them. Through ICL they could discuss, encourage and help each other. Students also mentioned that the quizzes enabled them to be more focused during the class session. In addition, the quizzes also motivated them to attend the class regularly.

Students also gave suggestions for improving ICL. Several students said they should be given a chance to re-do their quizzes so that they could remember their mistakes and would not repeat them. Several students mentioned that the lecturers should ask questions to individual students as this would allow them to be more focused in class. The general remark mentioned by students was about the size of the classroom which was not big enough and was quite crowded. 
The findings indicated that a majority of the students valued the new learning experience as well as each other's contribution to the success of their group. Most of the students preferred this new way of learning because they could discuss the learning materials, exercises, quizzes, and assignments with their group members. This made them realize how much they actually understood or misunderstood the topics discussed.

\subsection{Challenges}

Infrastructure and classroom size were critical factors in the success of ICL. The classroom provided was only suitable for a normal lecture where the students would sit separately. This sitting arrangement was not suitable for ICL, thus students had to rearrange their sitting according to their group during ICL. Furthermore, there must be enough space for the lecturers to walk around from one group to another. Most of the time, students took around five minutes of class time to sit in their group. Thus, it would be better if ICL was conducted in a specific classroom with an arrangement that could support the cooperation of the students where they could easily sit according to their group.

\section{Conclusion}

This paper discusses the authors' experience in implementing team-teaching in an informal cooperative learning classroom. Implementing team-teaching was an empowering experience for the authors. The findings indicated that team-teaching helped the lecturers to better manage and organize their class. Team-teaching assisted the lecturers to develop intellectual team-working and to be more effective in their teaching. Team-teaching approach could benefit new lecturers by pairing them with experienced lecturers. It is a form of mentoring for new lecturers, having the opportunity to expand their knowledge on the subject matter as well as to improve their teaching skills and quality. In addition, several challenges and difficulties in individual implementation of ICL classroom were reduced. It should be noted that the authors continue to team-teach until today. Depending on a number of students in the class, the students are divided into two students per group or three students per group. Based on our experienced, four students per group are not very suitable.

Students' experiences while learning and participating in the ICL classroom are also discussed. Students enjoyed and valued the new learning experiences as ICL environment taught them to become more responsible and to appreciate their own and others' contribution to the success of their group. Participating in group discussions also helped them to improve their communication skills and the way they interacted with their classmates. Team-teaching also contributed to the positive development of students when they observed the way the lecturers communicated and cooperated in managing the class. 


\section{$6 \quad$ References}

[1] Johnson, D. W., Johnson, R. T., \& Holubec, E. J. (1994). New circles of learning: Cooperation in the classroom and school. Alexandria, VA: ASCD.

[2] Johnson, D. W. \& Johnson, R. T. (1999). Making cooperative learning work. Theory into Practice, 38(2), 67-73. Retrieved from: http://www.jstor.org/stable/1477225 https://doi. org/10.1080/00405849909543834

[3] Smith, K. A. (1996). Cooperative learning: Making groupwork work. New Directions for Teaching and Learning, 67, pp. 71-82. https://doi.org/10.1002/tl.37219966709

[4] Gillies, R. M., \& Boyle, M., (2010). Teachers' reflections on cooperative learning: Issues of implementation. Teaching and Teacher Education, 26, pp. 933-940. https://doi.org/10.10 16/j.tate.2009.10.034

[5] Wang, T.P. (2007). The comparison of the difficulties between cooperative learning and traditional teaching methods in college English teachers. The Journal of Human Resource and Adult Learning, 3(2), pp. 23-30.

[6] Chiriac, E. H., \& Granström, K. (2012). Teachers' leadership and students' experience of group work. Teachers and Teaching, 18(3), 345-363, https://doi.org/10.1080/13540602.20 12.629842

[7] M. Abdullah, "Teaching Reflection,”, 2015, unpublished.

[8] Goetz, K. (2000). Perspectives on team teaching. EGallery, 1(4). Retrieved from: http://peo ple.ucalgary.ca/ egallery/goetz.html

[9] https://cft.vanderbilt.edu/guides-sub-pages/setting-up-and-facilitating-group-work-usingcooperative-learning-groups-effectively//

[10] Felder, R. M., \& Brent, R. (2007). Cooperative learning. In Mabrouk, P.A. (Ed.), ACS Symposium Series 970. Active learning: Models from the analytical sciences. (pp. 34-53). Washington, DC: American Chemical Society. https://doi.org/10.1021/bk-2007-0970.ch00 $\underline{4}$

[11] Ling, E. K. H. (2006). A teacher's personal reflection on the usage of cooperative learning strategies in teaching primary school science. Jurnal Penyelidikan Tindakan, 1, 12-28. Retrieved from: http://www.ipbl.edu.my/portal/penyelidikan/JurnalActionResearch/2006/3\% 20Eileen.pdf

[12] Aydin, S. (2011). Effect of cooperative learning and traditional methods on students' achievements and identifications of laboratory equipment in a science-technology laboratory course. Educational Research and Reviews, 6(9), 636-644.

[13] Johnson, D. W., Johnson, R. T., \& Smith, K. A. (1998). Active learning: Cooperation in the college classroom (2nd ed.). Edina, MN: Interaction Book.

[14] Johnson, D. W., \& Johnson, R. T. (2009). An educational psychology success story: Social interdependence theory and cooperative learning. Educational Researcher, 38, 365. https:// doi.org/10.3102/0013189x09339057

[15] Chapman, R. M. (2008, Fall/Winter). Team teaching for relevance in technology. NACCE Journal. Retrieved from: http://www.nacce.com/news/35103/Team-Teaching-for-Relevanc e-inTechnology.htm

[16] Baeten, M. \& Simons, M. (2016). Student teachers' team teaching: how do learners in the classroom experience team-taught lessons by student teachers?, Journal of Education for Teaching, 42:1, 93-105, https://doi.org/10.1080/02607476.2015.1135226

[17] https://education.stateuniversity.com/pages/2493/Team-Teaching.html

[18] Al-Saaideh, M. (2010). A rational to adopt team teaching in prevocational education in Jordan. Journal of Instructional Psychology, 37 (4): pp. 269-285. 
[19] Leavitt, M. C., (2006, Fall). Team teaching; Benefits and challenges. Center for Teaching and Learning Newsletter, Stanford University, 16(1), 1-4. Retrieved from: http://web.stan ford.edu/dept/CTL/Newsletter/teamteaching.pdf

[20] Carpenter, D. M., Crawford, L., \& Walden, R. (2007). Testing the efficacy of team teaching. Learning Environments Research, 10(1), pp. 53-65. https://doi.org/10.1007/s10984-00 7-9019-y

[21] https://www.sagepub.com/sites/default/files/upm-binaries/36584_01_Koshy_et_al_Ch_01. pdf

[22] Altrichter, H., Feldman, A., Posch, P., \& Somekh, B. (2008). Teachers investigate their work: An introduction to action research across the professions (2nd ed.). London: Taylor \& Francis Group.

[23] Sagor, R. (2000). Guiding school improvement with action research. Alexandria, VA: Association for Supervision and Curriculum Development.

\section{$7 \quad$ Authors}

Kamilah Radin Salim, Morina Abdullah, Habibah Norehan Haron, Noor Hamizah Hussain and Ruzana Ishak work for Universiti Teknologi Malaysia, Skudai, Malaysia

Article submitted 2019-07-12. Resubmitted 2019-08-22. Final acceptance 2019-08-27. Final version published as submitted by the authors. 


\section{Appendix}

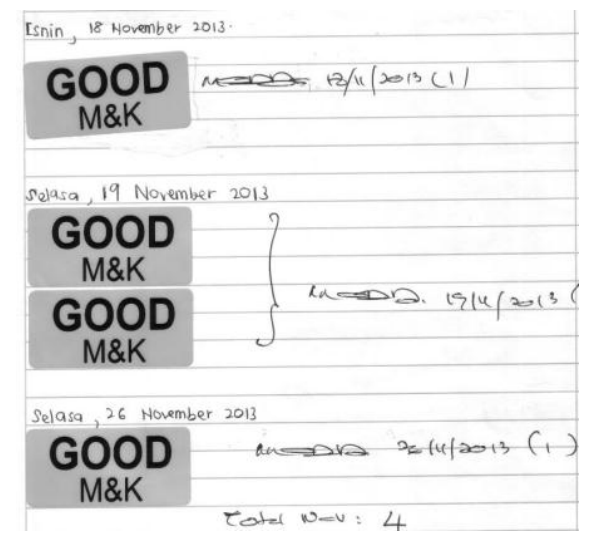

Fig. 1. Example of a student's notebook

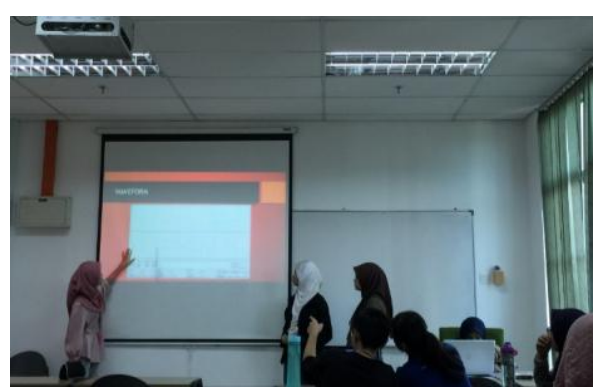

Fig. 3. Group Work

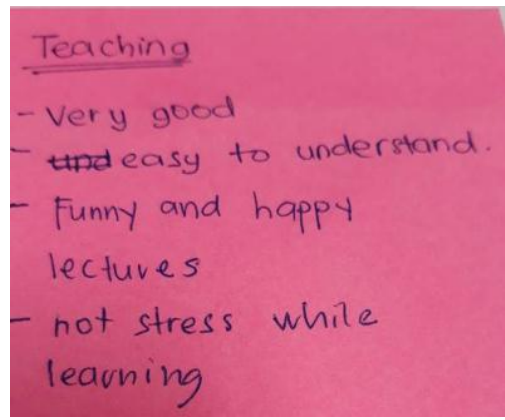

Fig. 5. Student's Reflection

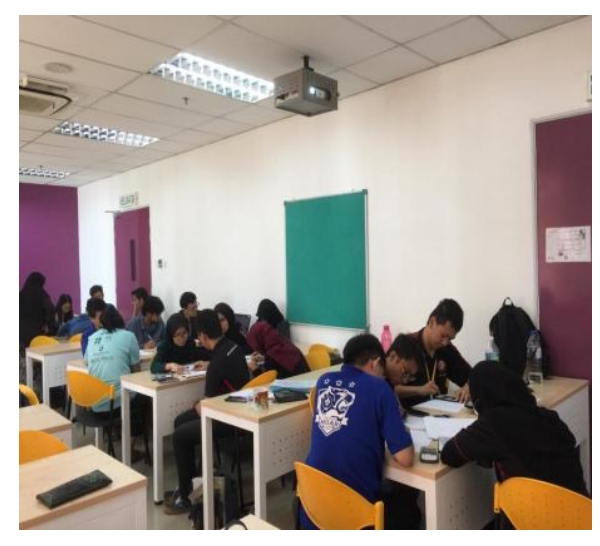

Fig. 2. Group Work

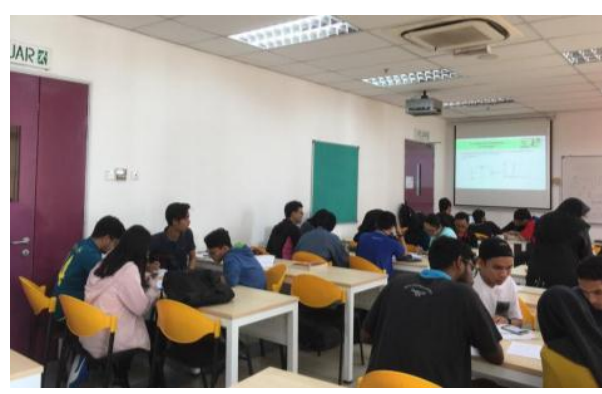

Fig. 4. Group Work

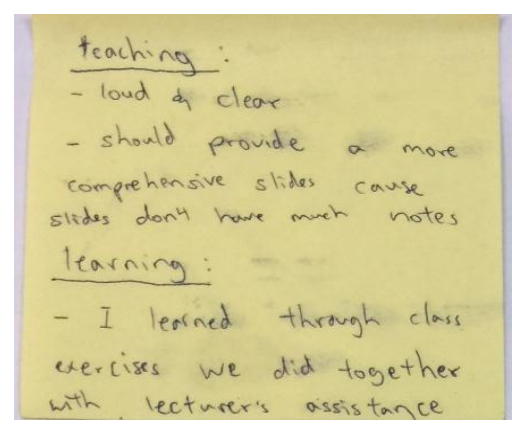

Fig. 6. Student's Reflection 